Rwanda Journal of Medicine and Health Sciences Vol.3 No.1 March 2020 https://dx.doi.org/10.4314/rjmhs.v3i1.2

\title{
Melatonin ameliorates ketoconazole-induced increase in thyroid function
}

\begin{abstract}
Abdullateef Isiaka Alagbonsi ${ }^{1 *}$, Luqman Aribidesi Olayaki ${ }^{2}$, Halimat Amin Abdulrahim ${ }^{3}$, Mariam Titilayo Suleiman², Israel Bojuwade ${ }^{2}$, Noah Adavize Omeiza ${ }^{2}$, Sheu Oluwadare Sulaiman ${ }^{4}$

${ }^{1}$ Department of Physiology, School of Medicine and Pharmacy, University of Rwanda College of Medicine and Health Sciences, Huye, Republic of Rwanda

${ }^{2}$ Department of Physiology, College of Health Sciences, University of Morin, Morin, Kwara, Nigeria

${ }^{3}$ Department of Medical Biochemistry, College of Health Sciences, University of Ilorin, Ilorin, Kwara, Nigeria

${ }^{4}$ Department of Physiology, Kampala International University Western Campus, Ishaka Bushenyi, Uganda.

*Corresponding author: Abdullateef Isiaka Alagbonsi; Department of Physiology, School of Medicine and Pharmacy, University of Rwanda College of Medicine and Health Sciences, Huye, Republic of Rwanda. Email: easylat@gmail.com
\end{abstract}

\section{ABSTRACT \\ Background}

The antithyroid effect of ketoconazole has been reported. The secretion and action of melatonin in the thyroid gland are also known. However, the possible effect of melatonin on ketoconazole-induced antithyroid effect is unknown.

\section{Objective}

We sought to investigate the modulatory effect of ketoconazole and/or melatonin on thyroid function in female rats.

\section{Methods}

Groups 1-4 of female rats respectively underwent 14-day treatment with normal saline, $25 \mathrm{mg} / \mathrm{kg}$ ketoconazole, $4 \mathrm{mg} / \mathrm{kg}$ melatonin and $10 \mathrm{mg} / \mathrm{kg}$ melatonin. Groups 5 and 6 both received 14-day treatment with ketoconazole and were respectively treated with $4 \mathrm{mg} / \mathrm{kg}$ melatonin and $10 \mathrm{mg} / \mathrm{kg}$ melatonin simultaneously. Groups 7 and 8 respectively underwent 14 -day pretreatment with $4 \mathrm{mg} / \mathrm{kg}$ melatonin and $10 \mathrm{mg} / \mathrm{kg}$ melatonin, followed by 14-day administration of ketoconazole to both groups. Groups 9 and 10 were both treated with ketoconazole for 14 days, followed by respective 14-day administration of $4 \mathrm{mg} / \mathrm{kg}$ melatonin and $10 \mathrm{mg} / \mathrm{kg}$ melatonin.

\section{Results}

TSH, T3, T4, and iodine concentrations were increased by separate administration of ketoconazole and either dose of melatonin when compared to control. However, pre-treatment or post-treatment of ketoconazoletreated rats with melatonin abolished the ketoconazole-induced increase in TSH, T3, T4, and iodine while co-administration of ketoconazole with melatonin caused no improvement in the ketoconazole-induced increase in TSH, T3, and T4 except iodine concentration.

\section{Conclusion}

Ketoconazole increased thyroid function, which was ameliorated by pre- or post-treatment with melatonin, possibly via modulation of the iodination process.

Keywords: Iodine; Ketoconazole; Melatonin; Thyroid function; Toxicity

\section{INTRODUCTION}

Ketoconazole is an artificial base broad-spectrum antimycotic drug. Ketoconazole was originally introduced for clinical treatment of genital candidiasis, superficial fungal infections, breast cancer, chronic mucocutaneous candidiasis, and prostatic carcinoma but also being used in the treatment of Cushing syndrome.[1-3] 
Ketoconazole destroys fungal membrane integrity and causes fungal death by inhibiting the synthesis of ergosterol from lanosterol through the inhibition of $14 \mathrm{a}$-demethylase that is a cytochrome P450 enzyme).[4] Ergosterol is a fungal cell membrane sterol that serves a similar function as cholesterol does in the animal cell membranes. $[4,5]$ The $14 a$-demethylase activity is also important in humans as it is involved in the formation of cholesterol,[6] and its inhibition causes endocrine disruption such as inhibition of steroidogenesis. $[7,8]$ Ketoconazole also directly or indirectly (via its metabolite, N-deacetyl ketoconazole) causes cellular toxicity (especially hepatotoxicity) $[9,10]$ that is mediated through oxidative stress.[11]

Ketoconazole was considered by the European Medicines Agency to be used in the European Union for the treatment of Cushing's Syndrome in patients above 12 years old.[12] The use of ketoconazole has been limited due to its toxicity despite its importance as an anti-fungal drug and a therapy for Cushing's disease management. Ketoconazole has been replaced with newer drugs with less toxicity and more effectiveness for the management of those diseases. [8,9] Ketoconazole is, therefore, an alternative drug that would only be prescribed during a special indication that must be strictly monitored especially for any disruption of liver function. $[3,13,14]$ Since oxidative stress is part of the mechanisms by which ketoconazole causes toxicity, the possible ameliorative effect of antioxidants like melatonin in some diseases caused by ketoconazole toxicity needs further investigation.

Melatonin, (N-acetyl-5-methoxy-tryptamine) is a neurohormone that has many functions in plants and animals.[15] In mammals, melatonin primary source is the pineal gland [16] but it is also secreted from extrapineal sources including the thyroid gland. $[17,18]$ Melatonin functions include regulation of chronobiology, oxidative stress, mitochondrial homeostasis, apoptosis,[19] oncostatic, anti-aging, and immunomodulatory activities.[18]

Melatonin activity has been confirmed in the thyroid gland. For instance, melatonin is produced by $\mathrm{C}$ cells under the influence of thyroidstimulating hormone (TSH), while melatonin receptor1 (MT1) is present in thyroid follicular cells.[17,20] Moreover, several effects of melatonin have been reported in the thyroid gland. Some of the effects include the protection of thyroid cells due to its antioxidant property,[21] reduction in the circulating thyroid hormones, [22] inhibition of thyroid cell proliferation and thyroid hormone synthesis,[23] as well as increased thyroid hormones under some condition.[24] Previous findings on the effect of ketoconazole on thyroid function are contradictory, though the majority of studies reported its antithyroid effect.[25,26] However, the regulatory effect of melatonin on ketoconazole effect(s) in the thyroid gland is not yet understood, which is the information this current study sought to provide using the rat model.

\section{METHODS}

\section{Animals}

Fifty (50) female Wistar rats weighing 160-180 g were housed in wooden cages. Before the study was commenced, the animals were maintained under standardized conditions $(50-80 \%$ relative humidity, $27-30^{\circ} \mathrm{C}$, and $12 \mathrm{~h}$ light/dark cycle), and acclimatized for 3 weeks in the Physiology departmental animal house, University of Ilorin. The rats had unrestricted access to water and standard rodent pelletized diet and were wellcatered following the criteria contained in the "Guide for the Care and Use of Laboratory Animals".[27]

\section{Experimental Design}

All the rats were randomly divided in a blinded fashion into 10 groups, each containing 5 rats. All the treatments were given via oral gavage and done once daily between 8:00 and 10:00 am.

Groups 1-4 respectively underwent 14-day treatment with normal saline, $25 \mathrm{mg} / \mathrm{kg}$ ketoconazole, $4 \mathrm{mg} / \mathrm{kg}$ melatonin and $10 \mathrm{mg} / \mathrm{kg}$ melatonin. Groups 5 and 6 both received 14-day treatment with ketoconazole and were respectively treated with $4 \mathrm{mg} / \mathrm{kg}$ melatonin and $10 \mathrm{mg} / \mathrm{kg}$ melatonin simultaneously. Groups 7 and 8 respectively underwent 14 -day pretreatment with $4 \mathrm{mg} / \mathrm{kg}$ melatonin and $10 \mathrm{mg} / \mathrm{kg}$ melatonin, followed by 14-day administration of ketoconazole to both groups. Groups 9 and 10 were both treated with ketoconazole for 14 days, followed by respective 14-day administration of $4 \mathrm{mg} / \mathrm{kg}$ melatonin and $10 \mathrm{mg} / \mathrm{kg}$ melatonin.

\section{Determination of Biochemical Parameters}

After 24 hours of the last treatment, the animals were anesthetized by exposing them to diethyl ether in a plastic container. Thereafter, they were dissected, and a blood sample from each animal was collected into separate heparinized bottles by cardiac puncture. The blood was then spun for 10 minutes at 4,000 revolutions per minute and the supernatant plasma from each centrifuged blood was transferred into separate plain bottles and stored at $20^{\circ} \mathrm{C}$ before assays of TSH, triiodothyronine $\left(\mathrm{T}_{3}\right)$, thyroxine (T4) and iodine using kits from Calbiotech (Spring Valley, CA). 


\section{Estimation of T3, T4, and TSH}

For the assay of T3, $50 \mu 1$ of the control, specimen, and serum reference were added into the designated well, followed by $100 \mu 1$ of T3-enzyme conjugate solution and gentle swirling for 20-30 seconds. For the assay of $\mathrm{T} 4,25 \mu \mathrm{l}$ of the standards, specimen, and control were added into the designated well, followed by the addition of 50 $\mu 1$ each of the working T4-enzyme conjugates solution and T4-antibody-biotin solution to all wells. For assay of TSH, $50 \mu \mathrm{l}$ of TSH standards, sample, and control were added into the designated wells and $100 \mu \mathrm{l}$ of the conjugate reagent was added. In all the assays, the microplate was then incubated for 60 minutes. The wells were emptied of the liquid and were washed three times with wash buffer, followed by blotting on absorbent paper towels. Then, $100 \mu 1$ of 3,3',5,5'-Tetramethylbenzidine substrate solution was added to all wells and the plates were then covered and incubated for 15 minutes, followed by $50 \mu$ of stop solution and gentle mixing for 15-20 seconds. Within 15 minutes of adding stop solution, the ELISA reading of the absorbance was done at $450 \mathrm{~nm}$. The concentration of T3, T4 or TSH was extrapolated from the standard curve plotted for each of them.

\section{Iodine assay}

Iodine assay was done with the microplate method as described.[28]

\section{Statistical Analyses}

The Statistical Package for Social Sciences (SPSS) version 22.0 (IBM Corporation, Armonk, NY) was used to analyze the data, which are expressed as mean \pm SEM. One-way analysis of variance (ANOVA) was used to compare data after which post hoc Least Significance Difference (LSD) for multiple comparison test was done. Groups that received ketoconazole or melatonin only were compared to the normal control group that received normal saline, while the groups that received a combination of ketoconazole and melatonin were compared to the one that received ketoconazole only; $p<0.05$ was considered statistically significant.

\section{RESULTS}

Effect of ketoconazole and/or melatonin on plasma thyroid-stimulating hormone (TSH) in rats

The TSH concentration was increased by separate administration of ketoconazole $(1.16 \pm 0.42 \mu \mathrm{M})$ and either $4 \mathrm{mg} / \mathrm{kg}(1.17 \pm 0.16 \mu \mathrm{M})$ or $10 \mathrm{mg} / \mathrm{kg}$
$(1.02 \pm 0.12 \mu \mathrm{M})$ of melatonin when compared to control $(0.46 \pm 0.05 \mu \mathrm{M})$. However, pre-treatment (4 $\mathrm{mg} / \mathrm{kg}: 0.51 \pm 0.14 \mu \mathrm{M} ; 10 \mathrm{mg} / \mathrm{kg}: 0.30 \pm 0.04 \mu \mathrm{M})$ or post-treatment $(4 \mathrm{mg} / \mathrm{kg}: 0.26 \pm 0.03 \mu \mathrm{M} ; 10$ $\mathrm{mg} / \mathrm{kg}: 0.17 \pm 0.08 \mu \mathrm{M}$ ) of ketoconazole-treated rats with either dose of melatonin abolished the ketoconazole-induced increase in TSH $(1.16 \pm 0.42$ $\mu \mathrm{M})$, while simultaneous administration of ketoconazole with $4 \mathrm{mg} / \mathrm{kg}(1.03 \pm 0.26 \mu \mathrm{M})$ and 10 $\mathrm{mg} / \mathrm{kg}(0.55 \pm 0.21 \mu \mathrm{M})$ of melatonin respectively caused no change and an improvement in ketoconazole-induced increase in TSH concentration $(1.16 \pm 0.42 \mu \mathrm{M})$ (Figure 1).

\section{Effect of ketoconazole and/or melatonin on plasma thyroid hormones concentration}

The triiodothyronine $\left(\mathrm{T}_{3}\right)$ concentration was increased by separate administration of either ketoconazole $(0.74 \pm 0.20 \mathrm{ng})$ or $10 \mathrm{mg} / \mathrm{kg}$ melatonin $(0.66 \pm 0.15 \mathrm{ng})$ but not $4 \mathrm{mg} / \mathrm{kg}$ melatonin $(0.37 \pm 0.07 \mathrm{ng})$ when compared to control $(0.26 \pm 0.04 \mathrm{ng})$. However, the ketoconazoleinduced increase in $\mathrm{T}_{3}$ was abolished by pretreatment $(0.34 \pm 0.05 \mathrm{ng})$ or post-treatment $(0.36 \pm 0.07 \mathrm{ng})$ of ketoconazole-treated rats with only $4 \mathrm{mg} / \mathrm{kg}$ melatonin. However, simultaneous treatment of ketoconazole and $4 \mathrm{mg} / \mathrm{kg}(0.88 \pm 0.15$ $\mathrm{ng})$ or $10 \mathrm{mg} / \mathrm{kg}(0.82 \pm 0.09 \mathrm{ng})$ of melatonin did not affect $\mathrm{T}_{3}$ when compared to rats that received ketoconazole only (0.74 $\pm 0.20 \mathrm{ng}$ ) (Figure 2A).

When compared to control $(1.17 \pm 0.10 \mathrm{ng})$, the thyroxine $\left(\mathrm{T}_{4}\right)$ concentration was increased by ketoconazole $(2.61 \pm 0.87 \mathrm{ng})$, which was abolished by post-treatment with $4 \mathrm{mg} / \mathrm{kg}(1.27 \pm 0.13 \mathrm{ng})$ and $10 \mathrm{mg} / \mathrm{kg}(1.18 \pm 0.16 \mathrm{ng})$ of melatonin. The ketoconazole-induced increase in $\mathrm{T}_{4}$ was neither affected by simultaneous treatment with $4 \mathrm{mg} / \mathrm{kg}$ $(2.29 \pm 0.24 \mathrm{ng})$ and $10 \mathrm{mg} / \mathrm{kg}(3.22 \pm 0.69 \mathrm{ng})$ of melatonin, nor with pre-treatment with $4 \mathrm{mg} / \mathrm{kg}$ $(2.93 \pm 0.33 \mathrm{ng})$ and $10 \mathrm{mg} / \mathrm{kg}(3.01 \pm 1.10 \mathrm{ng})$ of melatonin (Figure 2B).

\section{Effect of ketoconazole and/or melatonin on plasma iodine concentration}

Ketoconazole $(60.19 \pm 4.62 \mu \mathrm{g})$ and $10 \mathrm{mg} / \mathrm{kg}$ melatonin $(66.84 \pm 12.36 \mathrm{ng})$ but not $4 \mathrm{mg} / \mathrm{kg}$ melatonin $(48.09 \pm 0.95 \mu \mathrm{g})$ increased iodine concentration when compared to control $(38.01 \pm 4.24 \mu \mathrm{g})$. The ketoconazole-induced increase in iodine was abolished by pretreatment with $4 \mathrm{mg} / \mathrm{kg}$ melatonin $(43.12 \pm 0.62 \mu \mathrm{g})$ and posttreatment with $10 \mathrm{mg} / \mathrm{kg}$ melatonin $(33.95 \pm 3.43$ $\mu \mathrm{g})$ but unaffected by simultaneous treatment with either $4 \mathrm{mg} / \mathrm{kg}(67.23 \pm 18.56 \mu \mathrm{g})$ or $10 \mathrm{mg} / \mathrm{kg}$ $(71.31 \pm 2.70 \mu \mathrm{g}$ ) of melatonin (Figure 3). 
四 Simultaneous $\quad$ III Pretreatment $\quad \mathbf{W}$ Posttreatment

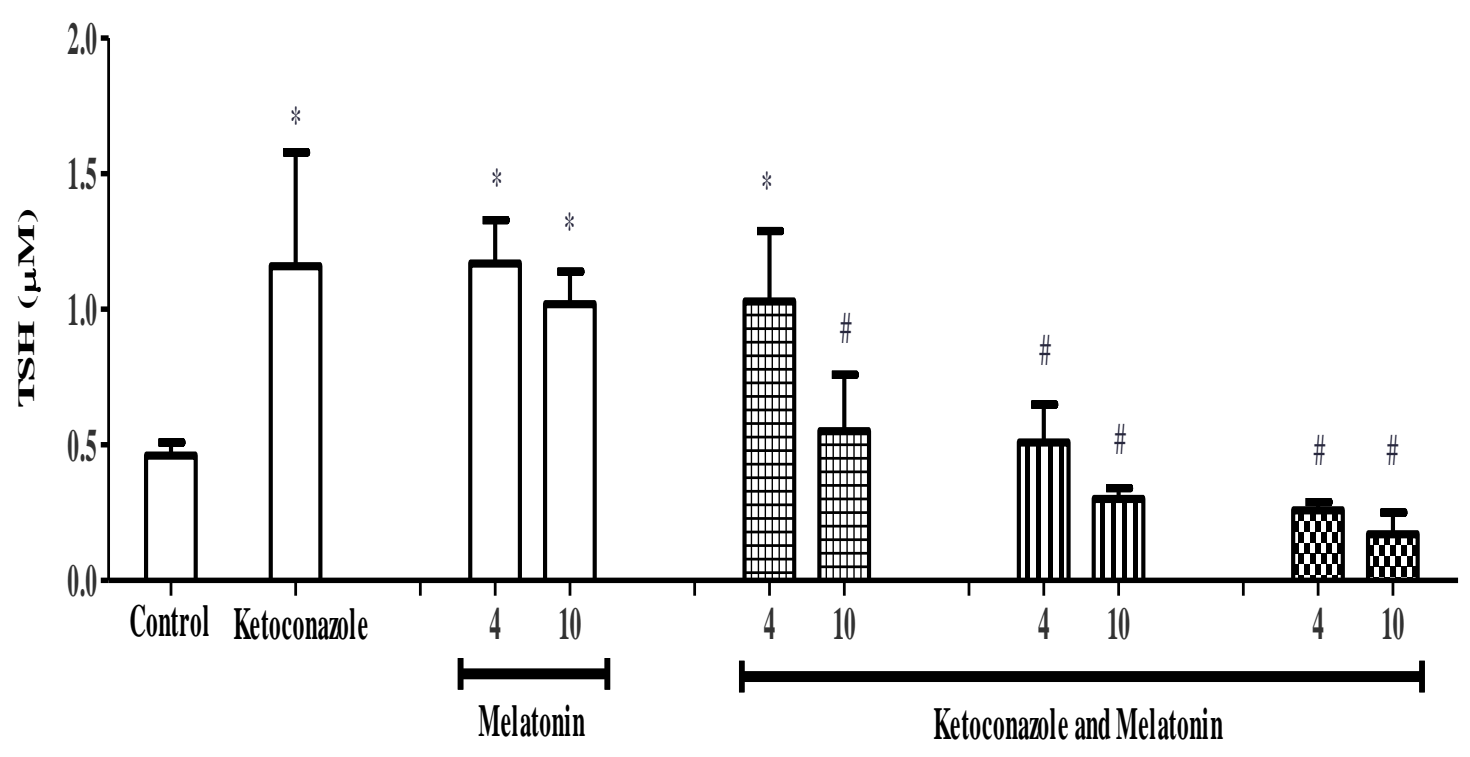

Figure 1. Effect of ketoconazole and/or melatonin on Thyroid Stimulating Hormone (TSH) in rats. " $p<0.05$ vs. control; ${ }^{*} p<0.05$ vs. ketoconazole. The doses of melatonin are represented as 4 and 10 below the corresponding bars.
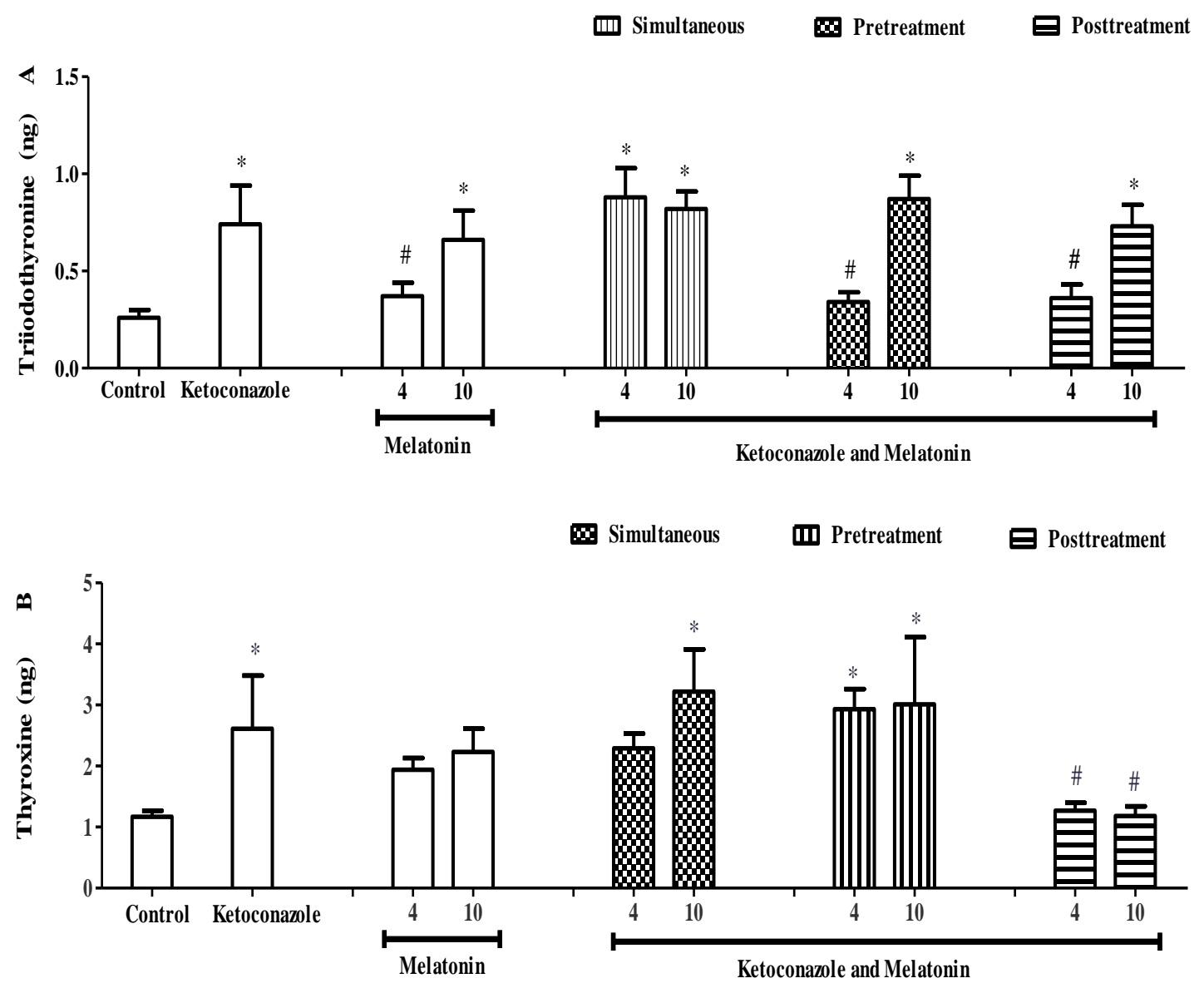

Figure 2. Effect of ketoconazole and/or melatonin on Triiodothyronine (A) and Thyroxine (B) concentrations in rats. " $p<0.05$ vs. control; ${ }^{\#} p<0.05$ vs. ketoconazole. The doses of melatonin are represented as 4 and 10 below the corresponding bars. 


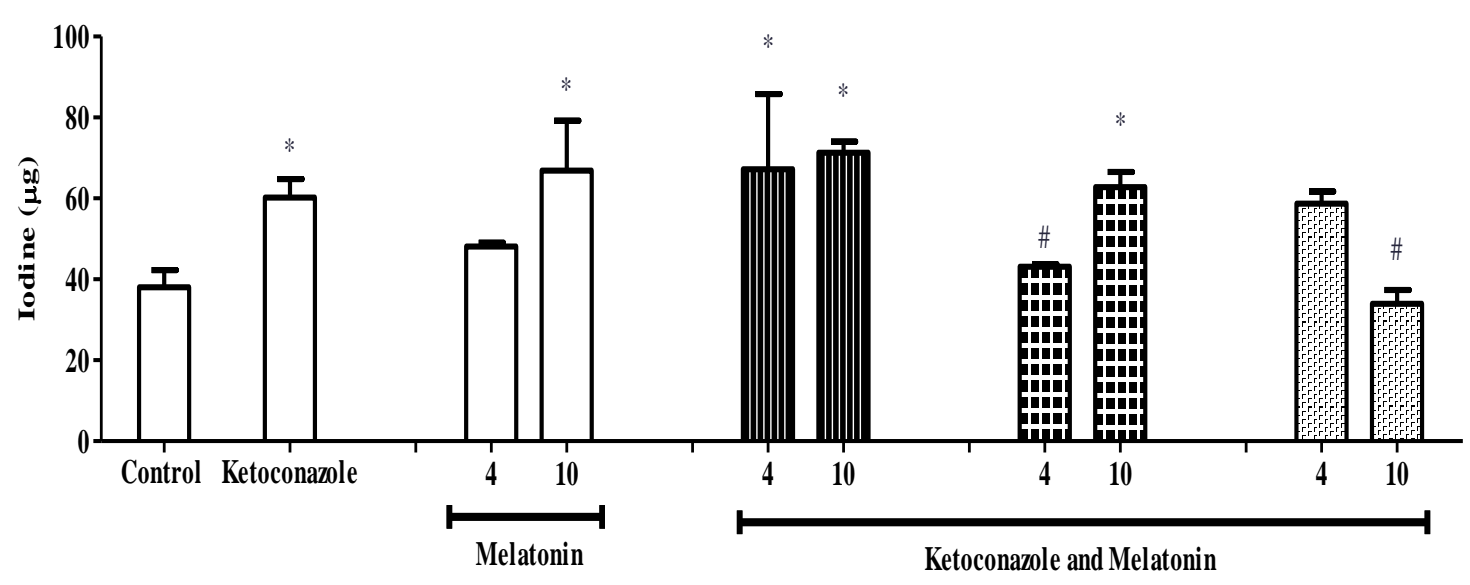

Figure3. Effect of ketoconazole and/or melatonin on iodine concentration in rats. ${ }^{*} p<0.05$ vs. control; ${ }^{*} p<0.05$ vs. ketoconazole. The doses of melatonin are represented as 4 and 10 below the corresponding bars.

\section{DISCUSSION}

The effect of Ketoconazole on thyroid hormone remains inconclusive, as there were reported discrepancies associated with the dose and duration of the studies. Shin et al.[29] reported decreased and unchanged levels of both thyroid hormones (T3 and T4) following administration of $100 \mathrm{mg} / \mathrm{kg} / \mathrm{d}$ and $25 \mathrm{mg} / \mathrm{kg} / \mathrm{d}$ ketoconazole. Twice-daily administration of $60 \mathrm{mg} / \mathrm{kg}$ ketoconazole reduced $\mathrm{T} 3$ and $\mathrm{T} 4$ at day 15 but increased TSH after 30 days in male rats.[26] Meanwhile, $600 \mathrm{mg} /$ day ketoconazole did not inhibit thyroid function and hormones synthesis, as it did not cause any change of thyroid hormones and TSH in normal, hypothyroid, and thyrotoxic patients.[30] In this study, we observed that 14-day treatment with ketoconazole increased plasma TSH and both thyroid hormones (T3 and T4).

The activities of thyroid hormones (T4 and T3) are known to be determined by three iodothyronine deiodinases, which consist of two 5'-deiodinases (D1 and D2) and one 5-deiodinase (D3).[31] D1, mainly found in tissues like liver, kidney, and thyroid, is primarily involved in the conversion (activation) of T4 to T3 in circulation, [32] but it can also inactivate the $\mathrm{T} 4$ by converting it to an inactive metabolite called reverse T3 (rT3). The D2 is found mainly in the pituitary, brain, and brown adipose tissue and it is crucial for the local conversion of T4 to T3 in the tissues and is more efficient in T4-T3 conversion than D1. Both D1 and D2 can convert the rT3 to 3,5-diiodo-Lthyronine (T2).[32] D3, mainly found in the brain, fetal tissues, and placenta, is important in the inactivation of locally and plasma-derived T3 to 3,5-diiodo-L-thyronine (T2) and prevents T4 activation to a lesser extent by converting the T4 to rT3.[31] Thus, the D3 pathway is the predominant means for the clearance of plasma T3. So, could ketoconazole-induced increase in TSH and thyroid hormones be associated with modulation of deiodinases?

Ketoconazole has been reported to inhibit D1 and D2, whose activities are also affected by thyroid status.[33] For instance, D1-catalyzed conversion of T4 to T3 reduces in hypothyroidism and is elevated in hyperthyroidism, while D2-catalyzed conversion of T4 to T3 increases secondary to the decreased levels of free T4 and T3 (hypothyroidism) but decreases in hyperthyroidism.[32] Previous studies have reported higher TSH secretion in D2 knockout (D2KO) mice than in normal mice.[34] The ketoconazole-induced increase in TSH observed in this study and others[26,29] can then lead to increased thyroid hormones (T4 and T3), which can inhibit D2 and further increase the TSH from the pituitary. Though we did not determine the levels of the deiodinases (which is one of the limitations of this study), we speculate that D2 might have been inhibited by ketoconazole.

Melatonin has been reported to stimulate the expression of thyroglobulin at the levels of mRNA and protein. This stimulation is not mediated via PAX8, a transcription factor involved in TSHmediated increased thyroglobulin expression but has been suggested to be a result of the oxidoreductive (antioxidant) effect of melatonin.[19] Sakamoto et al.[35] reported an increase in TSH and TSH-secreting cells in pars tuberalis of rats, which correlate with melatonin increase. A rise in plasma T3 and T4 have also been reported at some hours after melatonin 
administration.[23] The increase in thyroid parameters in our present study agrees with these previous reports.

However, pre-treatment and post-treatment (but not simultaneous treatment) of ketoconazoletreated rats with melatonin showed the abolishment of ketoconazole-induced thyrotoxicity. Melatonin-induced reduction in TSH, T4, and T3 [22] have been widely reported and these reductions occurred along with reduced thyroid follicle diameter, height, and proliferation.[23] In a $54 \mathrm{~h}$ tadpole thyroid culture, there was reduced T4 during the first $30 \mathrm{~h}$ but not during the remaining $24 \mathrm{~h}$ and there was reduced T3 during the first $12 \mathrm{~h}$ but the T3 increased above control for the remaining period.[23]

The reduced thyroid parameters in ketoconazoleadministered rats pretreated or post-treated with melatonin might result from both drug interaction, as ketoconazole has been shown to increase tasimelteon (a novel melatonin receptor agonist) activity because of its ability to inhibit
CYP3A4/5.[36] It could also result from modulation of iodothyronine deiodinases in the brain, thyroid gland and peripheral tissues by melatonin, [37] and protective activity of melatonin against any oxidative stress [38] that might have been induced by ketoconazole. These then suggest that melatonin can increase or reduce thyroid parameters depending on conditions such as duration and time of administration, [39] concentration and light/dark cycle, [40] type of the animal,[41] and drug-drug interaction.

In conclusion, pre- or post-treatment with melatonin (especially $4 \mathrm{mg} / \mathrm{kg}$ ) could ameliorate the disruption of the hypothalamic-pituitarythyroid axis caused by ketoconazole (see graphical abstract). Further studies are necessary to determine the roles of melatonin on nuclear T3, formation and receptor activities of thyrotropinreleasing hormone (TRH), TSH, T4, and T3; as well as on iodothyronine deiodinases levels in the thyroid gland, brain, and peripheral tissues of the ketoconazole-treated animal.

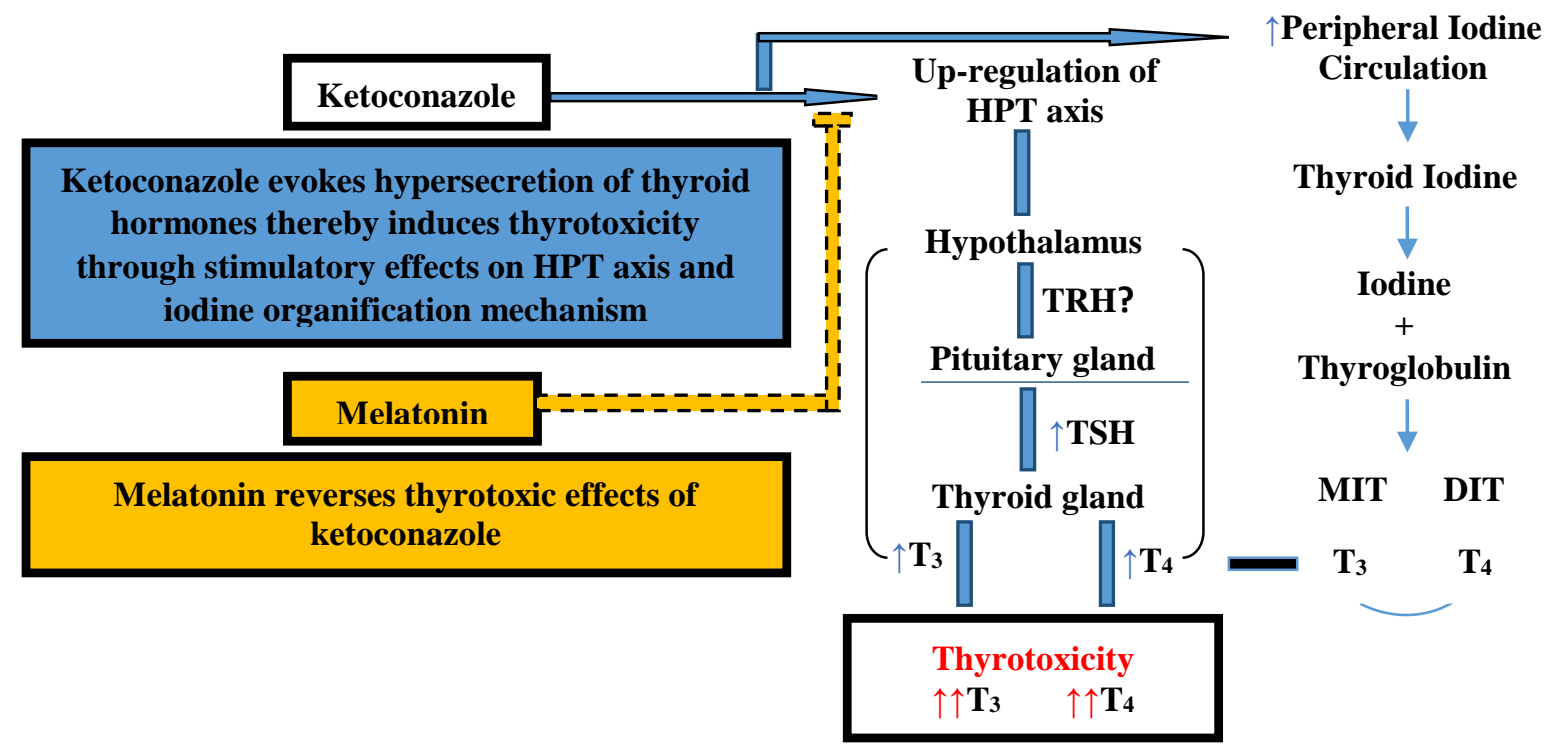

Figure 4. Graphical abstract

\section{Disclosure Statement}

None declared

\section{Funding}

None
This article is published open access under the Creative Commons Attribution-Non Commercial No Derivatives (CC BYNC-ND4.0). People can copy and redistribute the article only for noncommercial purposes and as long as they give appropriate credit to the authors. They cannot distribute any modified material obtained by remixing, transforming or building upon this article.

See https://creativecommons.org/licenses/bync-nd/4.0/ 
Rwanda Journal of Medicine and Health Sciences Vol.3 No.1 March 2020 https://dx.doi.org/10.4314/rjmhs.v3i1.2

\section{REFERENCES}

1. Gupta AK, Sauder DN, Shear NH. Antifungal agents: An overview. Part I. J Am Acad Dermatol. 1994;30:677-98.

2. Lo Re V, Carbonari DM, Lewis JD, Forde KA, Goldberg DS, Reddy KR, et al. Oral Azole Antifungal Medications and Risk of Acute Liver Injury, Overall and by Chronic Liver Disease Status. Am J Med. 2016;129:283-291.e5.

3. Tritos NA, Biller BMK. Medical management of Cushing's disease. J Neurooncol. 2014;117:407-14.

4. Becher R, Wirsel SGR. Fungal cytochrome P450 sterol 14a-demethylase (CYP51) and azole resistance in plant and human pathogens. Appl Microbiol Biotechnol. 2012;95:825-40.

5. Weete JD, Abril M, Blackwell M. Phylogenetic Distribution of Fungal Sterols. Butler G, editor. PLoS One. 2010;5:e10899.

6. Lepesheva GI, Waterman MR. Sterol 14alphademethylase cytochrome P450 (CYP51), a P450 in all biological kingdoms. Biochim Biophys Acta. 2007;1770:467-77.

7. Castinetti F, Guignat L, Giraud P, Muller M, Kamenicky P, Drui D, et al. Ketoconazole in Cushing's Disease: Is It Worth a Try? J Clin Endocrinol Metab. 2014;99:1623-30.

8. Nieman LK, Biller BMK, Findling JW, Murad MH, Newell-Price J, Savage MO, et al. Treatment of Cushing's Syndrome: An Endocrine Society Clinical Practice Guideline. J Clin Endocrinol Metab. 2015;100:2807-31.

9. Yan JY, Nie XL, Tao QM, Zhan SY ZY. Ketoconazole associated hepatotoxicity: a systematic review and meta- analysis. Biomed Env Sci. 2013;26:605-10.

10. Greenblatt HK, Greenblatt DJ. Liver injury associated with ketoconazole: Review of the published evidence. J Clin Pharmacol. 2014;54:1321-9.

11. Periasamy S, Liu C-T, Chien S-P, Chen Y-C, Liu $\mathrm{M}-\mathrm{Y}$. Daily sesame oil supplementation mitigates ketoconazole-induced oxidative stress-mediated apoptosis and hepatic injury. J Nutr Biochem. 2016;37:67-75.

12. Gupta AK, Lyons DCA. The Rise and Fall of Oral Ketoconazole. J Cutan Med Surg. 2015;19:352-7.

13. Gupta AK, Daigle D, Foley KA. Drug safety assessment of oral formulations of ketoconazole.
Expert Opin Drug Saf. 2015;14:325-34.

14. Fleseriu M, Petersenn S. Medical therapy for Cushing's disease: adrenal steroidogenesis inhibitors and glucocorticoid receptor blockers. Pituitary. 2015;18:245-52.

15. Tan DX, Hardeland R, Manchester LC, Paredes SD, Korkmaz A, Sainz RM, Mayo JC, Fuentes-Broto $\mathrm{L}$ RR. The changing biological roles of melatonin during evolution: from an antioxidant to signals of darkness, sexual selection and fitness. Biol Rev Camb Philos Soc. 2010;85:607-23.

16. Zawilska JB, Skene DJ, Arendt J. Physiology and pharmacology of melatonin in relation to biological rhythms. Pharmacol Rep. 2009;61:383410.

17. García-Marín R, de Miguel M, Fernández-Santos JM, Carrillo-Vico A, Utrilla JC, Morillo-Bernal J, et al. Melatonin-synthesizing enzymes and melatonin receptor in rat thyroid cells. Histol Histopathol. 2012;27:1429-38.

18. Acuña-Castroviejo D, Escames G, Venegas C, Díaz-Casado ME, Lima-Cabello E, López LC, et al. Extrapineal melatonin: sources, regulation, and potential functions. Cell Mol Life Sci. 2014;71:29973025.

19. Hardeland $R$, Cardinali DP, Srinivasan V, Spence DW, Brown GM, Pandi-Perumal SR. Melatonin-A pleiotropic, orchestrating regulator molecule. Prog Neurobiol. 2011;93:350-84.

20. Garcia-Marin R, Fernandez-Santos JM, MorilloBernal J, Gordillo-Martinez F, Vazquez-Roman V, Utrilla JC, et al. Melatonin in the thyroid gland: regulation by thyroid-stimulating hormone and role in thyroglobulin gene expression. J Physiol Pharmacol. 2015;66:643-52.

21. Tan D-X, Manchester LC, Liu X, Rosales-Corral SA, Acuna-Castroviejo D, Reiter RJ. Mitochondria and chloroplasts as the original sites of melatonin synthesis: a hypothesis related to melatonin's primary function and evolution in eukaryotes. J Pineal Res. 2013;54:127-38.

22. Petterborg LJ, Rudeen PK. Effects of Daily Afternoon Melatonin Administration on Body Weight and Thyroid Hormones in Female Hamsters. J Pineal Res. 1989;6:367-73.

23. Wright ML, Cuthbert KL, Donohue MJ, Solano $\mathrm{SD}$, Proctor KL. Direct influence of melatonin on the thyroid and comparison with prolactin. J Exp Zool. 2000;286:625-31. 
24. Wright ML, Pikula A, Cykowski LJ, Kuliga K. Effect of Melatonin on the Anuran Thyroid Gland: Follicle Cell Proliferation, Morphometry, and Subsequent Thyroid Hormone Secretionin Vitroafter Melatonin Treatmentin Vivo. Gen Comp Endocrinol. 1996;103:182-91.

25. O'Connor JC. Evaluation of a 15-Day Screening Assay Using Intact Male Rats for Identifying Steroid Biosynthesis Inhibitors and Thyroid Modulators. Toxicol Sci. 2002;69:79-91.

26. Çaksen H, Tutuş A, Kurtoğlu S, Öztürk F, Okumuş Y, Çoksevim B. Low Dose Ketoconazole Therapy and Thyroid Functions in Rats. Acta Medica (Hradec Kral Czech Republic). 2002;45:1779.

27. Guide for the Care and Use of Laboratory Animals. Guid. Care Use Lab. Anim. Washington, D.C.: National Academies Press; 2011.

28. Ohashi T, Yamaki M, Pandav CS, Karmarkar MG, Irie M. Simple microplate method for determination of urinary iodine. Clin Chem. 2000;46:529-36.

29. Shin J-H, Moon HJ, Kang IH, Kim TS, Kim IY, Park IS, et al. Repeated 28-day oral toxicity study of ketoconazole in rats based on the draft protocol for the "Enhanced OECD Test Guideline No. 407" to detect endocrine effects. Arch Toxicol. 2006;80:797803.

30. De Pedrini P, Tommaselli A, Montemurro G. No effect of ketoconazole on thyroid function of normal subjects and hypothyroid patients. Int $\mathrm{J}$ Clin Pharmacol Res. 1988;8:485-8.

31. Yang F, Ma H, Belcher J, Butler MR, Redmond TM, Boye SL, et al. Targeting iodothyronine deiodinases locally in the retina is a therapeutic strategy for retinal degeneration. FASEB J. 2016;30:4313-25.

32. Bianco AC, Kim BW. Deiodinases: implications of the local control of thyroid hormone action. J Clin Invest. 2006;116:2571-9.

33. Maia AL, Goemann IM, Meyer ELS, Wajner SM. Deiodinases: the balance of thyroid hormone: type 1 iodothyronine deiodinase in human physiology and disease. J Endocrinol. 2011;209:283-97.

34. Schneider MJ, Fiering SN, Pallud SE, Parlow AF, St. Germain DL, Galton VA. Targeted Disruption of the Type 2 Selenodeiodinase Gene ( DIO 2) Results in a Phenotype of Pituitary Resistance to T 4. Mol Endocrinol. 2001;15:2137-48.

35. Sakamoto S, Nakamura K, Inoue K, Sakai T. Melatonin stimulates thyroid-stimulating hormone accumulation in the thyrotropes of the rat pars tuberalis. Histochem Cell Biol. 2000;114:213-8.

36. Ogilvie BW, Torres R, Dressman MA, Kramer WG, Baroldi P. Clinical assessment of drug-drug interactions of tasimelteon, a novel dual melatonin receptor agonist. J Clin Pharmacol. 2015;55:100411.

37. Banks R, Delibegovic M, Stevenson TJ. Photoperiod- and Triiodothyronine-dependent Regulation of Reproductive Neuropeptides, Proinflammatory Cytokines, and Peripheral Physiology in Siberian Hamsters ( Phodopus sungorus ). J Biol Rhythms. 2016;31:299-307.

38. Zasada K, Karbownik-Lewinska M. Comparison of potential protective effects of melatonin and propylthiouracil against lipid peroxidation caused by nitrobenzene in the thyroid gland. Toxicol Ind Health. 2015;31:1195-201.

39. Goto M, Matsuo H, Iigo M, Furuse M, Korf H-W, Yasuo S. Melatonin-induced changes in the expression of thyroid hormone-converting enzymes in hypothalamus depend on the timing of melatonin injections and genetic background in mice. Gen Comp Endocrinol. 2013;186:33-40.

40. Edwards MLO, Pivorun EB. The effects of photoperiod and different dosages of melatonin on metamorphic rate and weight gain in Xenopus laevis tadpoles. Gen Comp Endocrinol. 1991;81:28-38.

41. Nurcan Dönmez, Fikret Karaca, Ferda Belge and CTA. The effects of melatonin application on some haematological parameters and thyroid hormones and testosterone in male goats' nonbreeding season. Vet Arh. 2004;74:281-7. 